\title{
Distribution and population separation of Bryde's whale Balaenoptera edeni off southern Africa
}

\author{
P. B. Best ${ }^{*}$ \\ Mammal Research Institute, University of Pretoria, Pretoria 0002, South Africa
}

\begin{abstract}
A review of available catch and biological data suggests that there are 3 populations of Bryde's whales in the southern African region. An inshore population (the South African Inshore Stock) occurs over the continental shelf of South Africa, south of about $30^{\circ} \mathrm{S}$, and seems to be nonmigratory, although there is a movement up the west coast in winter. A pelagic population (the Southeast Atlantic Stock) occurs on the west coast of southern Africa, ranging from equatorial regions to about $34^{\circ} \mathrm{S}$, and appears to migrate north in autumn and south in spring. Whales from the Southeast Atlantic Stock differ from the South African Inshore Stock in size, scarring, baleen shape, seasonality of reproduction, fecundity and prey types. Both occurred in the west coast whaling ground off Donkergat, but with differing seasonalities and distributions from the coast. Bryde's whales are rare on the east coast of southern Africa, but are found in summer in some numbers south of Madagascar. Whales from this population are clearly smaller than those from the Southeast Atlantic Stock, but are similar in size to, or even smaller than, those from the South African Inshore Stock. Their external appearance is unknown, but they differ in prey type from the South African Inshore Stock, and because of a clear discontinuity in distribution it is believed that they form a third (pelagic) population (the Southwest Indian Ocean Stock). This population may or may not move north as far as the Seychelles in winter, but seems to be separate from Bryde's whales in the Arabian Sea. From their size composition, length at sexual maturity and infrequent capture, Bryde's whales taken at Durban may have represented strays from either the South African Inshore Stock or the Southwest Indian Ocean Stock, and recorded stomach contents also indicate prey types common to either stock. The unusual degree of population differentiation shown by Bryde's whales may be a consequence of their limited seasonal migrations and apparent resource partitioning.
\end{abstract}

KEY WORDS: Bryde's whale · Distribution · Population separation · Southern Africa

Resale or republication not permitted without written consent of the publisher

\section{INTRODUCTION}

Following a visit to South African land stations at Donkergat (Saldanha Bay) and Durban in 1912/13, Ørjan Olsen described a new species of rorqual Balaenoptera brydei. This description was based solely on external morphology, including characteristics of the

*South African Museum, PO Box 61, Cape Town, 8000 South Africa. E-mail: pbest@samuseum.ac.za baleen (Olsen 1913). Subsequently this species was synonymised with $B$. edeni, based on a skeletal comparison (Junge 1950). Further research at Saldanha Bay in the 1960s revealed the existence of 2 forms ('inshore' and 'offshore') of Bryde's whales, differing in distribution, seasonality, body size, baleen shape, scarring, food type and possibly breeding behaviour (Best 1977). Subsequently, the taxonomy of Bryde's whales has been thrown into some confusion by the finding that local populations in several parts of its range show differences in body size (Perrin et al. 1996), and by the 
discovery of a 'dwarf' form genetically very different from other Bryde's whales so far examined (Wada \& Numachi 1991).

Given this confusion, and the importance of South African Bryde's whales in the taxonomic history of the species, this paper reviews the evidence for separate populations of Bryde's whales in the region, using a variety of data on distribution, morphology, reproduction and feeding. While genetic data undoubtedly would have strengthened this review, at present there are insufficient tissue samples available to make meaningful inter-population comparisons, although the collection of appropriate material is under way.

\section{MATERIAL AND METHODS}

The following data sets have been used in this paper: (1) Donkergat whaling station - 31 Bryde's whales landed in 1958 (Best 1960) and 578 Bryde's whales landed between 1962 and 1966 (Best 1977); (2) Durban whaling station - 43 Bryde's whales landed between 1962 and 1974 (Best 1977); (3) MV 'Run/Sierra'—statistics of 1645 'sei' whales landed, 1971-78 (Best 1996); (4) shipboard survey for inshore Bryde's whales on the south and west coasts of South Africa, 'Kyo Maru 27', 21 January to 14 February 1983 (Best et al. 1984); (5) whale marking cruises off Kwazulu-Natal and the Eastern Cape, South Africa, 24 January to 3 February 1968, 11 August to 1 September 1969, 31 January to 20 February 1971, 1 to 21 February 1972, 1 to 21 February 1973 and 18 to 31 January 1975; (6) whale marking cruise in the western Indian Ocean, 24 November 1973 to 3 February 1974 (Gambell et al. 1975); (7) special sci- entific catch of 105 Bryde's whales, south of Madagascar, March 1977 (Ohsumi 1980a); (8) Japanese scouting boat operations in the western Indian Ocean from 1976/77 to 1978/79 (Ohsumi 1980a); (9) IWC/SOWER blue whale cruise, southwest Indian Ocean, December 1996/January 1997; and (10) catches of Bryde's whales by Soviet whaling fleets in the western Indian Ocean: 'Sovietskaya Ukraina' 1964/65 (n = 457), 'Slava' 1965/ 66 ( $\mathrm{n}=136)$ and 'Sovietskaya Rossia' 1971/72 ( $\mathrm{n}=485)$, Zemsky et al. (1995), Mikhalev (2000).

Males were classified on histological examination of a testis sample as mature, immature or maturing (Best 1969), while mature females were those with at least 1 corpus in the ovaries.

As most length measurements were originally taken in feet and inches and rounded to the nearest foot, they have been cited as such and metric equivalents given in brackets.

\section{RESULTS}

\section{Distribution}

\section{Southeast Atlantic Ocean}

In the west coast whaling ground off Donkergat, the catch positions of Bryde's whales from 1962 to 1966 fell into 2 main areas of concentration, one inshore of the $200 \mathrm{~m}$ isobath, and the other somewhat offshore of the $400 \mathrm{~m}$ isobath (Best et al. 1984). This produced bimodality in the distribution of animals from the coast, with one peak at 0 to 20 nautical miles and the second at 50 to $100 \mathrm{n}$ miles from shore (Best 1977). These have subsequently been referred to as the inshore and off-

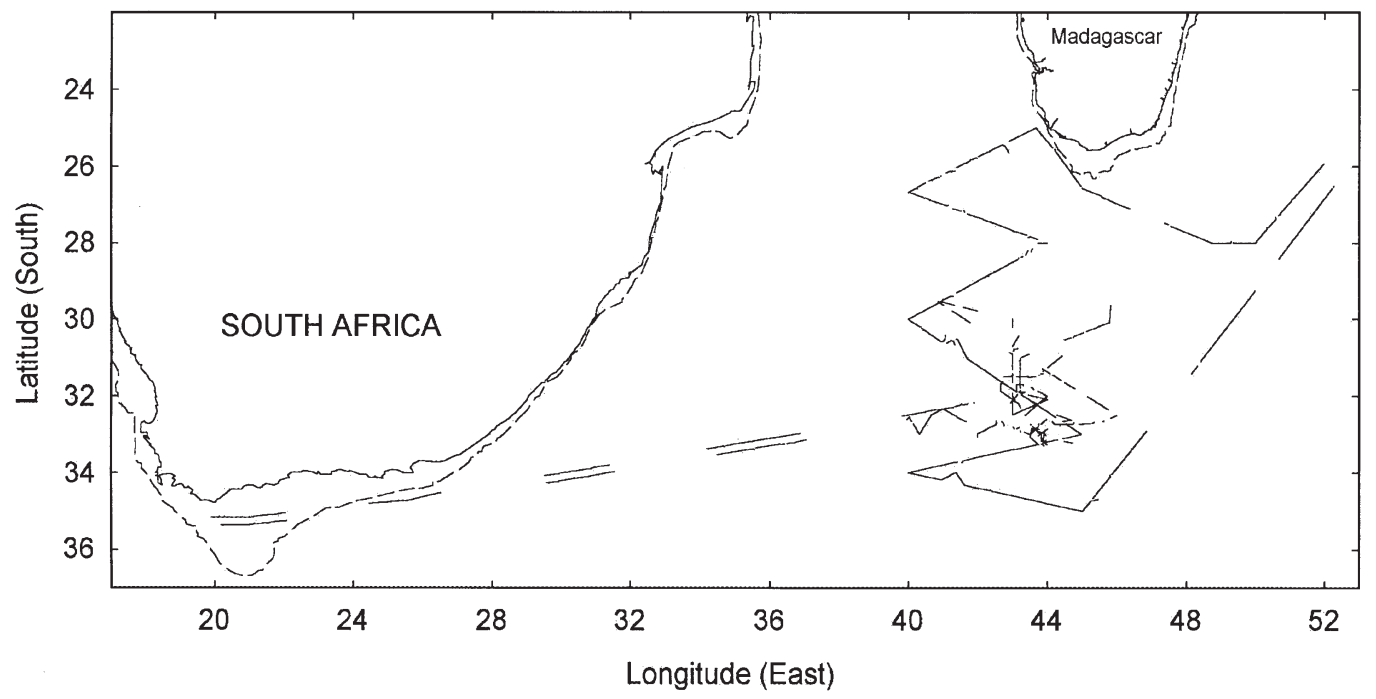

Fig. 1. Searching effort by 'Shonan Maru' and 'Shonan Maru no. 2' in the southwest Indian Ocean, December 1996/January 1997 (dashed line $=200 \mathrm{~m}$ isobath) 
shore populations respectively. The former is recognised as the South African Inshore Stock by the International Whaling Commission, while the latter has been termed the Southeast Atlantic Stock in this paper.

A catcher/factory ship the MV 'Run/Sierra' operating on the west coast of southern Africa between 1971 and 1978 took 1645 'sei' whales, which circumstantial (and some direct) evidence suggests were Bryde's whales from the offshore population (Best 1996). The combined catch positions of these whales indicate a continuous distribution from $32^{\circ} \mathrm{S}$ on the west coast of South Africa to $3^{\circ} \mathrm{N}$ off the coast of Cameroon, mostly within $300 \mathrm{n}$ miles of the coast.

A shipboard survey of the continental shelf of South Africa between the Orange River mouth (ca 29 ${ }^{\circ} \mathrm{S}$ ) on the west coast and East London (at ca $28^{\circ} \mathrm{E}$ ) on the south coast in January/February 1983 showed that the inshore population of Bryde's whales was mainly distributed between Cape Agulhas (20 E) and East London in summer (Best et al. 1984).

Bryde's whales appear to be rare on the east coast of South Africa (east of East London). On marking cruises off Kwazulu-Natal and the Eastern Cape in February 1968, August/September 1969, January/February 1971, February 1972, February 1973 and January 1975, in which a total of $104 \mathrm{~d}$ was spent at sea, Bryde's whales were only found within a $40 \mathrm{n}$ mile radius of Cape Recife, Port Elizabeth. This suggests that the inshore population does not usually range much further east than East London, at least in summer. As a species, they did not appear to be common in the Durban whaling ground (a fact also noted by Olsen 1913): during the whaling seasons (April to October) of 1962 to 1974, only 43 Bryde's whales were taken, or an average of
$3.3 \mathrm{yr}^{-1}$. There was no marked bimodality of catches with distance from the shore (Best 1977).

\section{Southwest Indian Ocean}

From 24 November 1973 to 3 February 1974, the whaler 'Pieter Molenaar' surveyed the waters of the western Indian Ocean from approximately 20 to $42^{\circ} \mathrm{S}$, 30 to $67^{\circ} \mathrm{E}$, but no Bryde's whales were identified in $7166 \mathrm{n}$ miles of searching (Gambell et al. 1975). This suggests that Bryde's whales are not common in the region, as is implied by their scarcity off Durban.

The activities of Japanese scouting boats from 1976/ 77 to $1978 / 79$ also showed very low densities of Bryde's whales in the western Indian Ocean, except on the east coast (and particularly south) of Madagascar (29 to $32^{\circ} \mathrm{S}, 44$ to $51^{\circ} 30^{\prime} \mathrm{E}$ ). In the latter region, a scientific catch of 105 Bryde's whales was made in 7 d during March 1977 (Ohsumi 1978, 1980a). In evaluating sightings of 482 Bryde's whales, made mainly by scouting vessels attached to Japanese factory ships in the Indian Ocean between 1972/73 and 1984/85, Kasuya \& Wada (1991) concluded that the Madagascar concentration seems to be isolated from the other concentrations of Bryde's whales in the Indian Ocean, except possibly for a concentration in the southern Arabian Sea $(0$ to $5^{\circ} \mathrm{N}, 50$ to $70^{\circ} \mathrm{E}$ ) in March.

Between 3 December 1996 and 3 January 1997, the 2 whale sighting vessels 'Shonan Maru' and 'Shonan Maru no. 2' searched the Madagascar Ridge region from about 23 to $33^{\circ} \mathrm{S}$, and between 40 and $45^{\circ} \mathrm{E}$, before transiting to Cape Town (Fig. 1). During this period, 15 sightings of Bryde's whales and 5 of 'like-

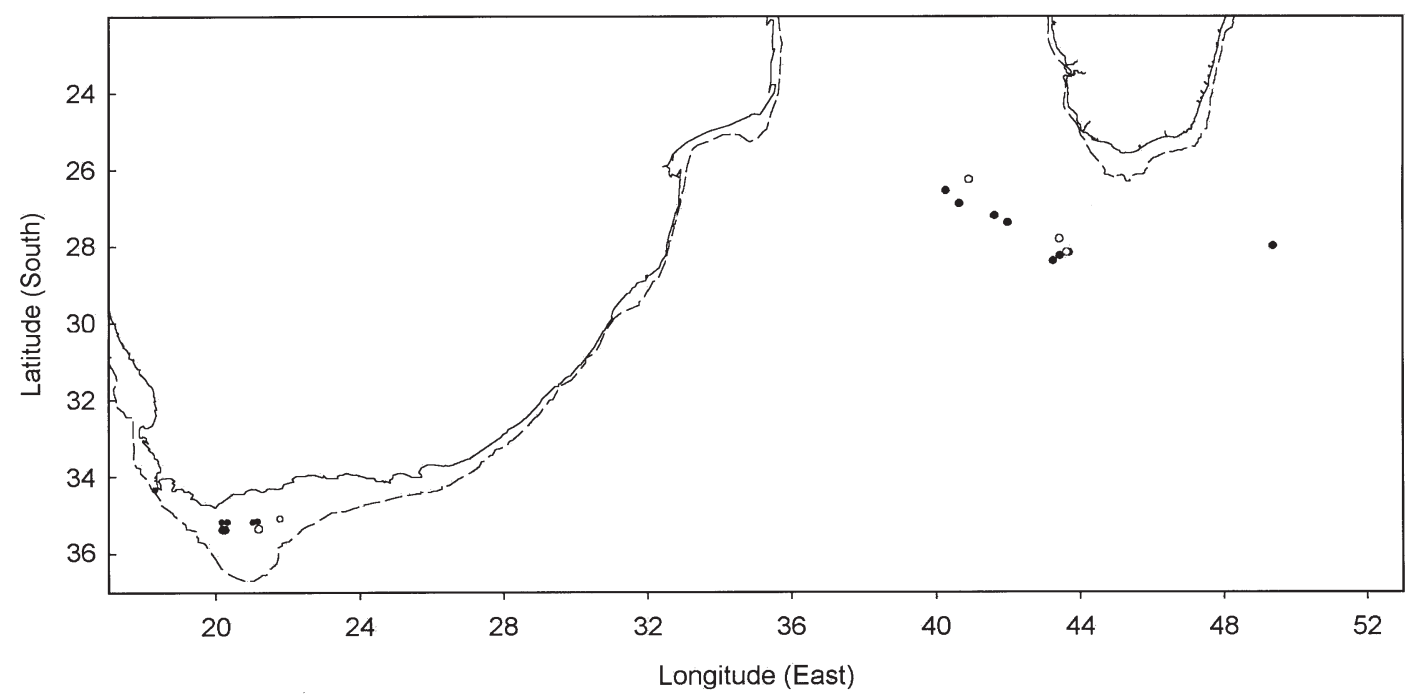

Fig. 2. Sightings of Bryde's whales (•) and like-Bryde's whales (o) from the 'Shonan Maru' and 'Shonan Maru no. 2', December 1996/ January 1997 
Bryde's' whales were made (Fig. 2). These fell into 2 groups: 8 sightings of Bryde's and 3 sightings of 'likeBryde's' to the south of Madagascar, and 7 sightings of Bryde's and 2 sightings of 'like-Bryde's' on the continental shelf at the southern tip of South Africa (presumably representing the inshore population in the southeast Atlantic).

Further north in the southwest Indian Ocean, sightings of large balaenopterid whales were made from French tuna vessels in the tropical Indian Ocean in the vicinity of the Seychelles Islands (Robineau 1991). Descriptions of these animals (about same size as sperm whales, without large flippers) and seasonality (most common in the austral summer) suggested that the majority of these might be Bryde's whales. Most $(97 \%)$ of the sightings were made between $5^{\circ} \mathrm{N}$ and $10^{\circ} \mathrm{S}$, and $45^{\circ}$ and $70^{\circ} \mathrm{E}$, and were especially numerous between 0 and $10^{\circ} \mathrm{S}$, and $55^{\circ}$ and $65^{\circ} \mathrm{E}$. The presence of these animals seemed to be environmentally determined, being linked with the Equatorial Counter Current from November to March/April: when the current changed with the Southwest Monsoon the whales apparently left the area.

In a survey of the western tropical Indian Ocean from March to July 1995, Ballance et al. (1996) recorded 8 sightings of Bryde's whales, all north of the equator, with 3 sightings in the sector 50 to $60^{\circ} \mathrm{E}$ and 5 in the sector 70 to $80^{\circ} \mathrm{E}$.

Over 4 seasons, Soviet whaling fleets made substantial annual catches of Bryde's whales in the Southern Hemisphere for which some indication of their timing and location is available. In November 1963, October to December 1964, November 1965 and November 1966, the 'Slava' and 'Sovietskaya Ukraina' expeditions took a combined total of 849 Bryde's whales in the Arabian Sea. While most of these were taken north of $5^{\circ} \mathrm{N}$, a separate concentration of catches occurred south of the equator, in the vicinity of the Seychelles Islands (Mikhalev 2000). In December 1971, the 'Sovietskaya Rossia' processed 483 Bryde's whales in Sector 3, of which 468 were in Zone $F$, or between 20 and $30^{\circ} \mathrm{S}$ : a map of the voyage shows that these catches must have been located at the southwestern tip of Madagascar (Zemsky et al. 1995).

\section{Size composition}

In Fig. 3 are shown the size compositions by sex of Bryde's whales of the inshore (119 females, 182 males) and offshore (66 females, 103 males) populations from Donkergat, and those of the 'sei' whales taken by the 'Sierra' in the southeast Atlantic (812 females, 777 males). For both sexes, whales taken by the 'Sierra' more closely resembled Bryde's whales from the offshore pop- ulation in their size distribution, and both were substantially larger than whales from the inshore population.

At Durban, both sexes ranged from 37 to $48 \mathrm{ft}$ (11.3 to $14.6 \mathrm{~m})$ in length, with a mode at $41 \mathrm{ft}(12.5 \mathrm{~m})$, while females had a secondary mode at $45 \mathrm{ft}$ (13.7 m) (Fig. 3), sizes more similar to inshore than to offshore whales from Donkergat (Ohsumi 1980a).

The Bryde's whales taken south of Madagascar in 1977 had a maximum size of $46 \mathrm{ft}$ (14.0 m) in males and $47 \mathrm{ft}(14.3 \mathrm{~m})$ in females, with modes at 40 to $42 \mathrm{ft}(12.2$ to $12.8 \mathrm{~m}$ ) in males and $43 \mathrm{ft}(13.1 \mathrm{~m})$ in females (Fig. 3). As Ohsumi (1980a) concluded, these animals seemed to be similar in size to those from Durban, and even smaller than the inshore animals from Donkergat.

The Bryde's whales from the Arabian Sea had a maximum length of 14.7 to $14.9 \mathrm{~m}$ in males and 15.3 to $15.5 \mathrm{~m}$ in females, with modes at 13.2 to $13.4 \mathrm{~m}$ in males and 13.5 to $13.7 \mathrm{~m}$ in females (Mikhalev 2000).

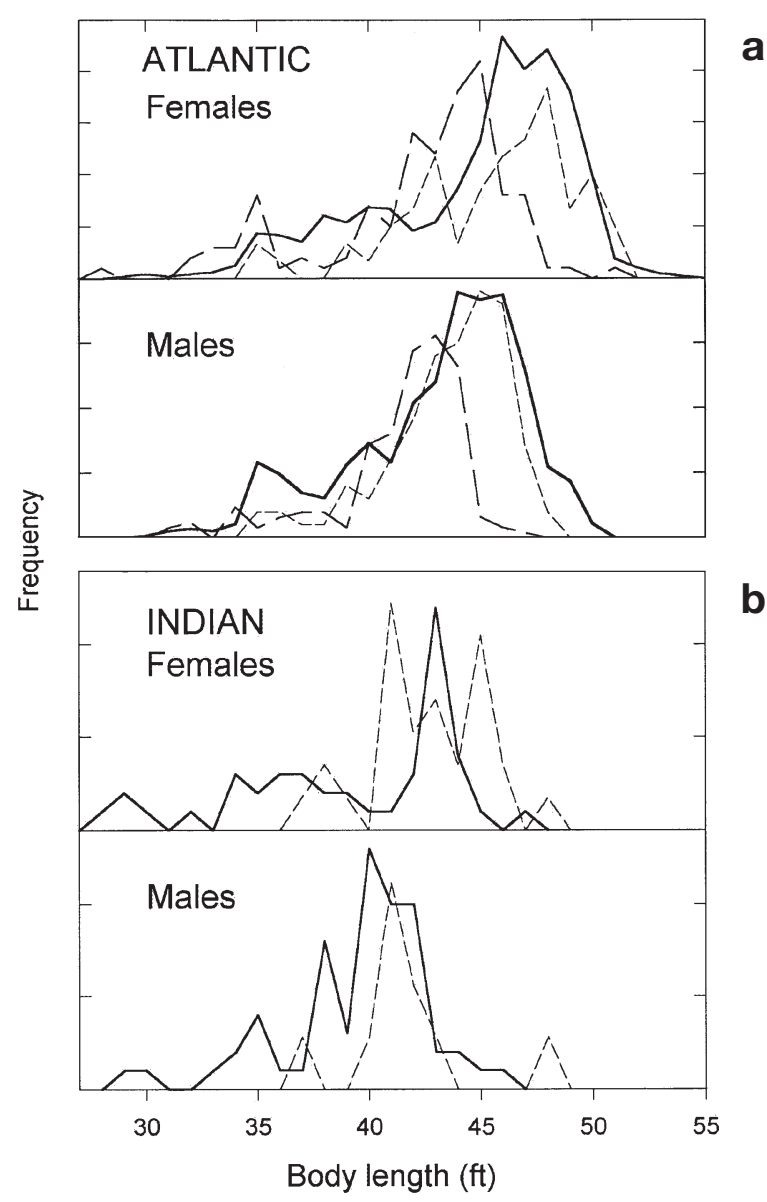

Fig. 3. Size compositions of catch of Bryde's whales in (a) South Atlantic Ocean (solid line = MV 'Sierra', broken line $=$ inshore whales at Donkergat, dashed line $=$ offshore whales at Donkergat) and (b) Indian Ocean (solid line = south of Madagascar, dashed line $=$ Durban) 


\section{Morphometrics}

A series of 13 body measurements was taken on 101 Bryde's whales landed at Donkergat whaling station in 1962 and 1963 (Best 1977). Although whales from the inshore population seemed to have a shorter rostrum and greater umbilical girth than whales from the offshore population, these differences were not statistically significant when each measurement was regressed against body length (both sexes combined). No significant differences could be found for any of the other 11 measurements when a similar analysis was carried out for whales less than 570 in (14.48 m) long (Best 1977).

A comparison of one of the largest baleen plates from 6 whales from each of the populations revealed that those from the inshore population were generally narrower than those from the offshore population (Best 1977). There appeared to be no significant difference in baleen bristle diameters between the 2 populations (mean of 0.46 and $0.49 \mathrm{~mm}$ for inshore and offshore whales respectively).

\section{External appearance, especially scarring}

All the Bryde's whales examined at Donkergat from 1962 to 1965 had the characteristic external features of the species, as previously described (Olsen 1913, Best 1960, Omura 1962). These included ventral grooves extending back at least as far as the umbilicus, and baleen with a 'bush' of coarse bristles at the tip. Smaller subsamples of the catch confirmed the presence of head ridges and (in $98.2 \%$ of animals) a median groove connecting the umbilicus to the genital aperture (Best 1977).

Specific notes were not made of coloration, but most $(98.4 \%)$ Bryde's whales of the offshore population at Donkergat bore many oval scars scattered over the body, particularly in the posterior half of the body, so that in older animals the skin bore the appearance of untarnished galvanised iron (Best 1977). These scars probably originated from the attacks of a small shark such as Isistius (Jones 1971). On the basis of similar scarring in sei whales, Shevchenko (1977) concluded that the waters off the west coast of southern Africa are a zone where such attacks occur. Most (94.4\%) Bryde's whales from the inshore population bore none or only a few of these scars, indicating that they were not normally distributed in this zone of attack.

Photographs and cine film taken on the 'Sierra' and viewed by the author have all indicated Bryde's whales with the heavy scarring typical of the offshore form.

The Bryde's whales landed at Donkergat also bore scarring of another kind. On the ventral surface of the flukes and along the keel of the ventral peduncle there were found long, thin scratches (usually healed) running in the same direction as the long axis of the whale. Such scars were found on $81.8 \%$ of whales from the inshore population, but in none from the offshore population (Best 1977). It is concluded that these injuries had been received when the whale was swimming in shallow water and its tail accidentally struck the seafloor.

No information on scarring is available for the Bryde's whale taken south of Madagascar.

Olsen (1913) described a Bryde's whale taken at Durban on 15 November 1912 as 'abnormal'. It was a female $14.95 \mathrm{~m}$ long, unusually slender and thin with numerous wounds distributed over the whole body. Illustrations clearly show that these wounds are typical of those made by a biting fish like Isistius. Other features of this 'abnormal' Bryde's whale mentioned by Olsen (1913) include the asymmetric coloration of the throat and baleen, which resembled that of a fin whale Balaenoptera physalus in that the lower jaw and distal part of the upper jaw were white on the right side but bluish black on the left. However, a Bryde's whale landed at Donkergat on 12 September 1912 (also illustrated by Olsen) clearly showed similar asymmetry of the throat coloration. His text also refers to whalers' reports that the baleen in some Bryde's whales was asymmetrically coloured as in fin whales, with one jaw having white baleen plates over a comparatively large section of the series, and the other jaw fairly uniformly coloured dark baleen. In several places, Olsen's original description of the species stresses the variability of the coloration of Bryde's whales, and it seems that the abnormal specimen may represent one extreme of that variation (a tendency for sei whales $B$. borealis to have asymmetrically coloured baleen has been noted by Brown 1965). It is also possible that such a pigmentation pattern is more prevalent in whales from the Southwest Indian Ocean Stock. If photographs of the scientific catch made south of Madagascar in 1977 still exist, this possibility could be investigated further.

\section{Reproduction}

Size at birth

At Donkergat, the largest foetus from an inshore whale was a $3.81 \mathrm{~m}$ female, and the largest foetus from an offshore whale a $3.96 \mathrm{~m}$ female. In the data set from the 'Sierra', there were 2 foetuses $3.81 \mathrm{~m}$ long, 7 foetuses $3.96 \mathrm{~m}$ long and 1 foetus $4.57 \mathrm{~m}$ long. The latter record, being $15 \%$ bigger than the next largest foetus, seems dubious; given the known imprecision of foetal measurements in most whaling operations (Best 1989), it has been considered a recording error. 
Two neonates stranded on the South African coast measured $3.81 \mathrm{~m}$ (from Willows, near Port Elizabeth, 1 July 1969) and $4.09 \mathrm{~m}$ (from Aasfontein, near Agulhas, 10 July 1984): both were female. It was impossible to assign either neonate to a specific population (inshore vs offshore).

With these small sample sizes, the size at birth is most appropriately given as the 'smallest neonate-largest

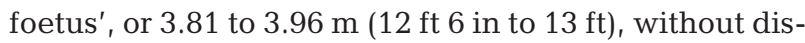
tinction as to population.

\section{Size at sexual maturity}

Information on maturity status was available for 71 male and 84 female Bryde's whales landed at Donkergat in 1958 and 1962-65 (Table 1). Ignoring pubertal ('maturing') males, and using the 'smallest mature largest immature' criterion, inshore males are estimated to attain maturity at $40-41 \mathrm{ft}(12.2-12.5 \mathrm{~m}) \mathrm{com}-$ pared to $42-45 \mathrm{ft}(12.8-13.7 \mathrm{~m})$ for offshore males, while inshore females reach sexual maturity at 39-41 ft (11.9-12.5 m) compared to 42-43 ft (12.8-13.1 m) for offshore females. Thus, while there was little apparent difference between sexes in the size at sexual maturity for either form, in both sexes inshore whales reached sexual maturity at sizes about 2 to $3 \mathrm{ft}(0.6$ to $0.91 \mathrm{~m})$ smaller than the offshore form.

Table 1. Reproductive maturity and size of Bryde's whales landed at Donkergat in 1958 and 1962-65 (Imm. = immature, Pub. = pubertal, Mat. = mature $)$.

$$
1 \mathrm{ft}=0.3048 \mathrm{~m}
$$

\begin{tabular}{|c|c|c|c|c|c|c|c|c|c|c|}
\hline \multirow{2}{*}{$\begin{array}{l}\text { Length } \\
\text { (ft) }\end{array}$} & \multicolumn{6}{|c|}{ Males $\longrightarrow$} & \multicolumn{4}{|c|}{ Females } \\
\hline & Imm. & $\begin{array}{l}\text { shor } \\
\text { Pub. }\end{array}$ & Mat. & Imm & $\begin{array}{l}\text { fsh } \\
\text { Pub }\end{array}$ & $\begin{array}{l}\text { e } \\
\text { Mat. }\end{array}$ & $\begin{array}{l}\text { Ins } \\
\text { Imm. }\end{array}$ & $\begin{array}{l}\text { ore } \\
\text { Mat. }\end{array}$ & $\begin{array}{l}\text { Off } \\
\text { Imm. }\end{array}$ & $\begin{array}{l}\text { hore } \\
\text { Mat. }\end{array}$ \\
\hline 32 & 1 & & & & & & & & & \\
\hline 33 & & & & & & & & & & \\
\hline 34 & & & & & & & 1 & & & \\
\hline 35 & & & & 1 & & & 1 & & 1 & \\
\hline 36 & 2 & & & 1 & & & & & & \\
\hline 37 & & & & & & & 1 & & & \\
\hline 38 & 2 & & & & & & & & 1 & \\
\hline 39 & 1 & & & 2 & & & & 1 & 2 & \\
\hline 40 & & & 1 & 2 & & & 1 & 1 & & \\
\hline 41 & 1 & & 4 & 3 & 1 & & 1 & & 3 & \\
\hline 42 & & & 5 & 1 & & 1 & & 3 & & 2 \\
\hline 43 & & 2 & 5 & & & 4 & & 2 & 1 & 4 \\
\hline 44 & & & & 1 & 3 & 3 & & 7 & & 1 \\
\hline 45 & & & & 1 & 3 & 3 & & 13 & & 6 \\
\hline 46 & & & 1 & & 1 & 7 & & 5 & & 5 \\
\hline 47 & & & & & & 5 & & 2 & & 5 \\
\hline 48 & & & 1 & & & 1 & & 1 & & 6 \\
\hline 49 & & & & & & 1 & & & & 2 \\
\hline 50 & & & & & & & & & & 3 \\
\hline 51 & & & & & & & & & & 2 \\
\hline Total & 7 & 2 & 17 & 12 & 8 & 25 & 5 & 35 & 8 & 36 \\
\hline
\end{tabular}

Although information on reproductive maturity was unavailable for the 'sei' whales taken by the MV 'Sierra', the incidence of pregnant females reached $50 \%$ of the average adult incidence of pregnancy between 43 and $44 \mathrm{ft}$ (13.1 and $13.4 \mathrm{~m}$ ) (Best 1996). Although not strictly comparable with the attainment of sexual maturity, this nevertheless suggests that these whales were closer in size to offshore than inshore Bryde's whales at Donkergat.

Reproductive information for 12 female Bryde's whales landed at Durban between 1962 and 1970 indicates that sexual maturity might be achieved at about $39 \mathrm{ft}(11.9 \mathrm{~m})$ (Best 1977), which is closer to the estimate for animals from the inshore population in the Western Cape (albeit from a very small sample).

For Bryde's whales taken in the scientific catch south of Madagascar, Ohsumi (1980a) estimated the length

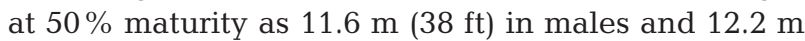
(40 ft) in females, similar to (or somewhat smaller than) those estimated for inshore Bryde's whales at Donkergat.

Data provided for 334 females taken in the Arabian Sea (Mikhalev 2000) indicates that $50 \%$ sexual maturity may be reached at a length of about $12 \mathrm{~m}$, similar to that for the whales taken south of Madagascar.

\section{Seasonality of breeding}

Amongst the Bryde's whales examined at Donkergat from 1962 onwards, there were 24 pregnant animals from the inshore population and 13 from the offshore population. Estimated conception dates for these foetuses were derived from the shape of the sei whale foetal growth curve and assuming a mean length at birth of $3.96 \mathrm{~m}$. The spread of these conception dates indicates that, while the breeding season in the inshore group might be unrestricted seasonally, that of the offshore whales probably peaked in autumn (Best 1977). To these can now be added 4 pregnant inshore and 4 pregnant offshore whales examined in 1958 (Best 1960).

An analysis of 218 foetuses from the 'Sierra' catch also indicates that the distribution of foetal lengths was not independent of the season, and that there was a peak in conceptions in late summer (Best 1996), a pattern very similar to that of the offshore whales at Donkergat. 


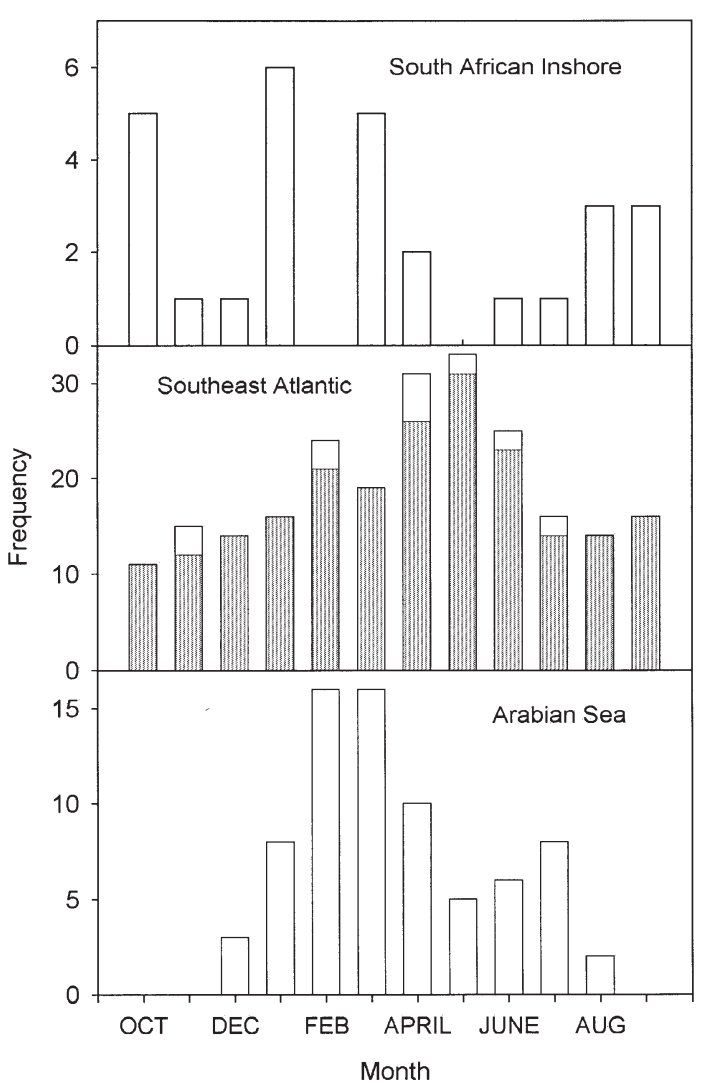

Fig. 4. Monthly distribution of apparent conceptions in Bryde's whales from the South African Inshore population, the Southeast Atlantic (hatched bars = data from MV 'Sierra', open bars = data from Donkergat) and the Arabian Sea

The foetal data from the 'Sierra' have now been reanalysed using the same method as in Best (1977), in order to obtain a more direct measure of the seasonal distribution of conceptions, and the results combined with those of the 17 foetuses from the offshore animals from Donkergat (Fig. 4). The results indicate that, although conceptions can occur in any month, their distribution is not uniform over the year (chi-square $=28.46, \mathrm{p}<0.005, \mathrm{df}=$ 11). The peak occurs between March and May, a period in which $38.0 \%$ of conceptions apparently take place. The data for the 28 inshore animals are also shown for contrast in Fig 4. If these data are grouped by season (December-February, March-May, June-August and September-November) to increase sample size, the proportions of conceptions in each do not differ significantly from parity (chi-square $=4.58, \mathrm{p}>0.1, \mathrm{df}=3$ ), indicating an apparent lack of seasonality.

There were only 5 pregnant females in the animals examined at Durban between 1962 and 1970, too few for any analysis of seasonality of reproduction (Best 1977). There were 9 pregnant females in the scientific catch south of Madagascar, taken over a period of only $7 \mathrm{~d}$. When these data were combined with another 46 foetuses from the eastern Indian Ocean and the southwest Pacific, Ohsumi (1980a) concluded that they perhaps supported the hypothesis that the distribution of conceptions was non-random throughout the year.

The seasonality of conception in the Bryde's whales taken in the Arabian Sea north of $5^{\circ} \mathrm{N}$ has been examined using data for 74 foetuses (the length of 1 set of twins averaged) given by Mikhalev (2000) and the approach of Best (1977) to obtain apparent conception dates (Fig. 4). The distribution of apparent conception dates by month was clearly not uniform over the year (chi-square $=57.97, \mathrm{p}<0.001$, df $=11$ ), with $67.6 \%$ occurring in 4 mo (December to February).

\section{Frequency of reproductive classes}

The reproductive condition of all mature female Bryde's whales examined at Donkergat in 1958 and 1962-65 is summarized by month in Table 2. There were only 35 mature females of each form examined, and temporal coverage is limited, non-pregnant females only being available for 3 mo in inshore animals and 5 mo in offshore animals. Proportions of pregnant, lactating and resting animals in inshore and offshore whales were $0.429,0.286$ and 0.286 , and $0.314,0.114$ and 0.571 respectively (Table 2). Ovulating animals occurred in the offshore population only in March and

Table 2. Reproductive condition of mature female Bryde's whales landed at Donkergat in 1958 and 1962-65 (Preg. = pregnant, Lact. = lactating, Rest. = resting, Ov. = ovulating)

\begin{tabular}{|c|c|c|c|c|c|c|c|c|c|c|}
\hline \multirow[t]{2}{*}{ Month } & \multicolumn{5}{|c|}{ Inshore form } & \multicolumn{5}{|c|}{ Offshore form } \\
\hline & Preg. & Lact. & Rest. & Ov. & Total & Preg. & Lact. & Rest. & Ov. & Total \\
\hline Mar & - & - & - & - & - & 3 & 0 & 2 & 1 & 6 \\
\hline Apr & - & - & - & - & - & 0 & 1 & 2 & 1 & 4 \\
\hline May & 1 & 0 & 0 & 0 & 1 & 1 & 0 & 10 & 0 & 11 \\
\hline Jun & 2 & 0 & 0 & 0 & 2 & 0 & 0 & 2 & 0 & 2 \\
\hline Jul & 5 & 1 & 0 & $1^{\mathrm{a}}$ & 7 & - & - & - & - & - \\
\hline Aug & 4 & 3 & 2 & $6^{\mathrm{b}}$ & 15 & - & - & - & - & - \\
\hline Sep & 3 & 4 & 0 & 3 & 10 & $1^{\mathrm{c}}$ & 0 & 0 & 0 & 1 \\
\hline Oct & - & - & - & - & - & 6 & 3 & 2 & 0 & 11 \\
\hline Total & 15 & 8 & 2 & 10 & 35 & 11 & 4 & 18 & 2 & 35 \\
\hline
\end{tabular}


April, whereas some ovulating females occurred in inshore animals in each of the 3 mo for which data were available. Two individuals from the inshore population were ovulating while lactating.

Data provided for 311 mature females taken in the Arabian Sea indicated proportions of $0.318,0.006,0.675$ for pregnant, lactating and resting females respectively (Mikhalev 2000). The proportion of lactating females reported seems unrealistically low, especially given the indiscriminate nature of Soviet whaling at the time (Golovlev 2000), but this is more likely to have affected the proportion of barren (resting) rather than pregnant animals reported.

\section{Frequency of ovulation}

The ovaries of Bryde's whales from the inshore population at Donkergat were typified by numbers of large corpora albicantia of similar sizes. An analysis of the largest corpus albicans in pregnant females showed that, whereas offshore whales all had corpora $3.0 \mathrm{~cm}$ or less, only $18.2 \%$ of inshore whales had corpora this small. The remaining $81.8 \%$ of inshore whales had corpora between 3.2 and $4.2 \mathrm{~cm}$ in diameter, with some animals having up to 4 corpora exceeding $3.0 \mathrm{~cm}$ in diameter. As there was no significant difference in the size of the corpus luteum of pregnancy in the 2 forms, it was assumed that the offshore form was seasonally monoestrous but that the inshore form might ovulate several times during a reproductive cycle, including during lactation. In support of this, 2 (or $22.2 \%$ ) lactating inshore whales were simultaneously ovulating, but no offshore animals. It was estimated that the average number of ovulations per reproductive cycle was 1.00 in offshore animals and 3.75 in inshore animals (Best 1977).

Two other pieces of information point to a higher fecundity in inshore whales. The proportions of ovulating (or possibly ovulating) animals amongst non-pregnant individuals were $50 \%$ in inshore animals but only $12 \%$ in offshore animals (Table 2). Secondly, the regressions of corpora number against age (as estimated from growth layers in the ear plug) gave a significantly higher ovulation rate of $2.35 \mathrm{yr}^{-1}$ for inshore whales compared to $0.42 \mathrm{yr}^{-1}$ for offshore whales (Best 1977). As a consequence, some inshore animals had as many as 43 and up to 55 corpora in the 2 ovaries combined, compared to a maximum of 27 in offshore animals.

\section{Feeding}

In the west coast whaling ground, $92.3 \%$ of the 39 Bryde's whales of the inshore form examined at Donkergat between 1962 and 1965 contained food. Apart from 1 stomach, with a mixture of maasbanker Trachurus trachurus and euphausiids Nyctiphanes capensis, all the other stomachs only contained fish remains, which in the case of 8 whales could not be identified. Of the remaining 27 whales, 11 contained only anchovies Engraulis capensis, 4 only maasbankers, 3 anchovies plus maasbankers, 3 anchovies, maasbankers and pilchards Sardinops ocellatus, and 6 anchovies and pilchards. The frequency of occurrence of different prey items is shown in Table 3, with species in mixed stomachs being allocated according to the proportions by number in samples drawn from some of the stomachs. The fish eaten were all of juvenile size classes (Best 1977). These stomachs were examined between April and September, 1962 to 1965.

During a sighting survey of the inshore population in summer (January/February 1983), Bryde's whales were seen consuming fish at the surface on 3 occasions. Fish collected on 2 of these occasions (once by net from the sea and once from the stomach of a diving gannet) proved to be adult anchovies (and a single mackerel Scomber japonicus). Diving gannets collected while in association with Bryde's whales on another 3 occasions had been feeding on anchovies (or unidentified fish). On the same cruise, faecal samples revealed feeding on shoaling squid Lycoteuthis diadema (2 samples from the same sighting), while another attempted sample produced dead and undi-

Table 3. Percent frequency of occurrence of prey items in stomachs of Bryde's (or assumed Bryde's) whales off southern Africa ( $\mathrm{n}=$ number of stomachs containing food)

\begin{tabular}{|c|c|c|c|c|}
\hline Prey item & $\begin{array}{l}\text { nshore Bryde's } \\
\quad(\mathrm{n}=39)\end{array}$ & $\begin{array}{l}\text { Offshore } \\
\text { Bryde's } \\
(\mathrm{n}=65)\end{array}$ & $\begin{array}{c}\text { 'Sei' whales } \\
\text { MV 'Sierra' } \\
(\mathrm{n}=934)\end{array}$ & $\begin{array}{l}\text { Madagascar } \\
\quad(\mathrm{n}=52)\end{array}$ \\
\hline \multicolumn{2}{|l|}{ Euphausiids, unidentified } & 48.5 & \multirow[t]{6}{*}{31.4} & 1.9 \\
\hline Euphausia recurva & & 6.6 & & $47.1^{\mathrm{a}}$ \\
\hline Euphausia lucens & & 24.3 & & \\
\hline Euphausia diomedea & & & & \multirow[t]{3}{*}{51.0} \\
\hline Thysanoessa gregaria & \multirow[t]{2}{*}{0.3} & 0.5 & & \\
\hline Nytiphanes capensis & & 0.8 & & \\
\hline Fish, unidentified & 22.2 & 10.0 & 68.6 & \\
\hline Engraulis japonicus & 61.2 & & & \\
\hline Trachurus trachurus & 14.7 & & & \\
\hline Sardinops ocellata & 1.6 & & & \\
\hline Maurolicus muelleri & & 4.6 & & \\
\hline Lestidium sp. & & 2.3 & & \\
\hline Scombrid sp. & & 2.3 & & \\
\hline
\end{tabular}


gested amphipods Themisto gaudichaudi, possibly the result of baleen flushing (Best et al. 1984). All these direct or indirect indications of feeding occurred on the south coast.

The incidence of food in the 78 offshore Bryde's whales examined in the west coast whaling ground between 1962 and 1965 was 83.3\%. Of the stomachs with food, $52(80 \%)$ contained euphausiids, $12(18.5 \%)$ fish, and $1(1.5 \%)$ a mixture of fish and euphausiid remains. The euphausiids eaten could be identified in 21 whales, of which 15 were eating Euphausia lucens, 4 E. recurva, 1 a mixture of E. lucens, E. recurva and Thysanoessa gregaria, and 1 a mixture of E. lucens and Nyctiphanes capensis. The fish eaten could be identified in 6 whales, of which 3 were eating Maurolicus muelleri, 1 Lestidium sp., 1 a mixture of Lestidium sp. and Scomberesox saurus, and 1 unidentified scombrids. These fish are all more mesopelagic in nature than those eaten by inshore Bryde's whales. The frequency of occurrence of different prey items is shown in Table 3, with species in mixed stomachs being allocated according to the proportions by number in samples drawn from some of the stomachs. These stomachs were examined between March and October, 1962 to 1965.

During whaling operations by the MV 'Sierra' on the west coast of southern Africa, the contents of the stomach of 1583 Bryde's whales were recorded, 934 $(59.1 \%)$ of which contained food. The incidence of food was higher in spring/summer than in autumn/winter. Of the stomachs containing food, 638 (68.3\%) were recorded as 'fish', 291 (31.1\%) as 'shrimps' (presumably euphausiids) and $5(0.5 \%)$ as 'fish and shrimps' (Table 3). There was a marked seasonality in prey type, with shrimps being relatively unimportant in autumn and winter (5.6 and 9.8\% respectively), becoming more important in spring $(21.3 \%)$ and predominating in summer $(74.7 \%)$. None of the material was specifically identified (Best 1996).

For 21 Bryde's whales with undamaged stomachs examined at Durban from 1962 to 1970, the incidence of food was low $(23.8 \%)$. Of the 5 animals containing food, 3 had fish (1 identified as 'sardines', 1 as 'Carangid sp.', and 1 unidentified), a fourth had 'shrimp remains' (presumably euphausiids) and 1 shoaling squid Lycoteuthis diadema.

The incidence of food in the Bryde's whales taken under special permit south of Madagascar in March 1977 was $46.7 \%$, and (apart from 1 hatchet fish taken with euphausiids) all these were feeding on euphausiids. Species involved (roughly equal in importance) were Euphausia recurva and E. diomedeae (Kawamura 1977).

Bryde's whales in the Arabian Sea fed mostly on lantern fish (Myctophidae), spotted mackerel Scomber tapeinocephalus, horse mackerel Trachurus spp., and sardines Sardinella spp., with euphausiids being infrequently eaten, although other crustaceans Squilla were taken (Mikhalev 2000).

\section{Seasonality and movements}

An earlier analysis of the catch data at Donkergat showed that Bryde's whales caught within $20 \mathrm{n}$ miles of the coast (or the inshore population) were taken in every month of the whaling season (March to October), but were more abundant from May to September. Whether this represented a change in availability with season was not clear, as the normal range of the catchers from Donkergat did not cover inshore waters (Best 1977). Subsequently, a sighting survey conducted in summer (January/February 1983) revealed that the bulk of the inshore population occurred on the south coast between Cape Agulhas and Port Elizabeth, and that there were relatively few Bryde's whales in the old whaling grounds off Donkergat. This evidence tended to support the hypothesis that there was a seasonal shift in the population of inshore Bryde's whales off the west coast of South Africa, with an influx occurring in winter (Best et al. 1984). Further evidence in support of such seasonality came in October/November 1993 from land- and boat-based surveys at Cape Columbine, about $15 \mathrm{n}$ miles north of the site of the Donkergat whaling station. During $424 \mathrm{~h}$ of watch from the shore, 195 sightings of whales were made, of which 62 were of humpback, 68 of right, 3 of fin and 3 of minke whales. The remaining sightings could not be identified to species, although 2 were categorised as unidentified balaenopterids, 1 as like-humpback, 8 as likeright and 4 as like-minke (Best et al. 1995). The lack of identified Bryde's (or even like-Bryde's) whale sightings indicates that inshore whales were very scarce in the area (and none was seen in $1112 \mathrm{~km}$ of searching by the ski-boat 'Ecklonia' as part of this same project). Consequently, it seems very likely that Bryde's whales of the inshore population move up the west coast in autumn and back again in spring: such shifts would correlate well with the movements of some of their major prey, pilchard and anchovy (Crawford 1980).

As pelagic fish, especially pilchards, extend up the east coast as far as northern Kwazulu-Natal in winter, it might be expected that inshore Bryde's whales would also move into Kwazulu-Natal waters seasonally. However, the biomass of fish involved is relatively low (only $4 \%$ of the total anchovy biomass, for instance), and the distribution narrowly confined against the coast (Armstrong et al. 1991), so that the available prey might only support a limited number of Bryde's whales. As discussed above, catches of Bryde's whales 
at the Durban whaling station were very low, relatively far offshore (only $9 \%$ within $20 \mathrm{n}$ miles of the coast) and not concentrated in winter (Best 1977). Any correlation with the northward extension of pelagic fish distribution in winter ('sardine run') is not obvious. Nevertheless, the few catches made within $20 \mathrm{n}$ miles of the coast were all taken in mid-winter (June/July), and $90 \%$ of the catches more than $60 \mathrm{n}$ miles offshore were taken in April and May. It is possible that the animals taken represented 'strays' from both the South African Inshore and the Southwest Indian Ocean Stocks.

There was an obvious seasonality in the catch of offshore Bryde's whales in the west coast whaling ground, with high numbers being taken in March, April and October, but very little in between (Best 1967). As the distribution of this population coincided to a great extent with the normal range of the catchers from Donkergat, this seasonality is not considered an artefact of searching effort. This implies that offshore whales moved out of the west coast whaling ground in winter.

The distribution of catches of 'sei' whales taken on the west coast of southern Africa by the MV 'Sierra' has been considered to reflect the distribution of off-

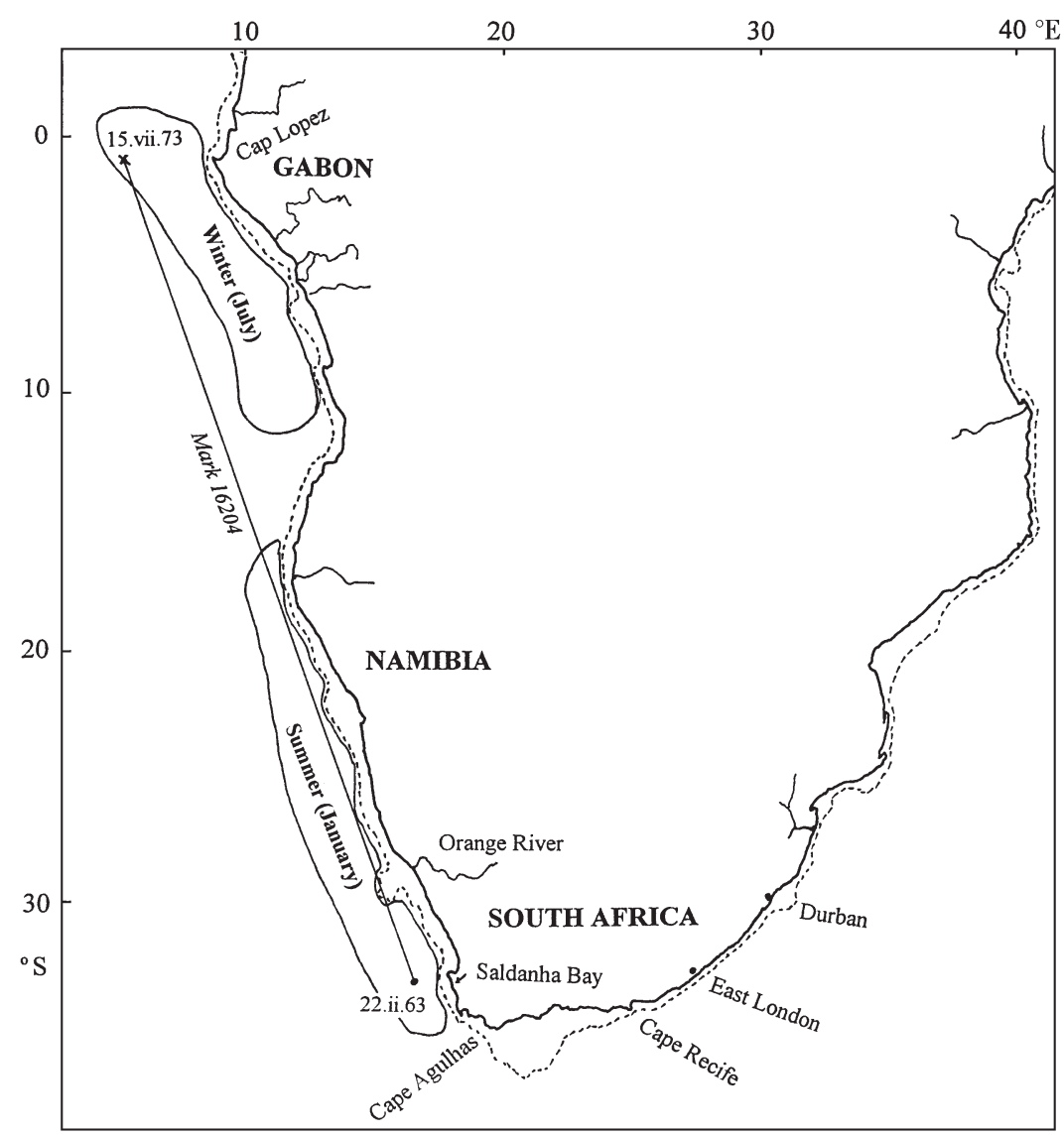

Fig. 5. Summer and winter distribution of 'sei' whales taken by MV 'Sierra', and the positions of firing and recovery of whale mark no. 16204 shore Bryde's whales accurately (Best 1996). On this assumption, the pattern of catching reveals a distinct north-south movement with the seasons, the whales being furthest north (centred off Gabon at ca $5^{\circ} \mathrm{S}$ ) in May, June, and July and furthest south (centred at about 25 to $28^{\circ} \mathrm{S}$ ) in January/February (Fig. 5). Catches were made off the west coast of South Africa only between November and April. This overall pattern agrees reasonably well with the absence of offshore Bryde's whales in the west coast whaling ground in winter, and their increasing abundance in March, April and October. It can be concluded therefore that the offshore Bryde's whales taken at Donkergat were part of a much wider-ranging population that migrates seasonally along the west coast of southern Africa.

This conclusion is supported by the recovery of a 'Discovery' whale mark fired into a 'sei' whale in February 1963, about 100 n miles west of Donkergat. In July 1973 this mark was recovered (from a 'sei' whale) on the MV 'Sierra' about 200 n miles west of Cap Lopez, Gabon, just south of the equator and a straight line distance of some $1960 \mathrm{n}$ miles from the position of marking (Fig. 5). Circumstantial evidence (including a subsequent cable from the 'Sierra') makes it highly probable that this was not a sei whale but a Bryde's whale (Best 1996). As such, it confirms the suggested pattern of movement of offshore Bryde's whales from summering grounds off South Africa/Namibia to wintering grounds off Gabon.

Seasonal movements (if any) of Bryde's whales from the Madagascar stock are unclear. For the Indian Ocean as a whole, Kasuya \& Wada (1991) concluded that the southern boundary of Bryde's whale distribution shifted from $15-20^{\circ} \mathrm{S}$ in October to $35-40^{\circ} \mathrm{S}$ from December to February. This suggests a southward movement in spring, as postulated for the Southeast Atlantic Stock. The sightings from the 'Shonan Maru' and 'Shonan Maru no. 2' in December, the 'Sovietskaya Rossia' catches in December 1971, and (to a lesser extent) the catches made south of Madagascar in March 1977 are in reasonable agreement with this pattern. However, the evidence from the Seychelles region suggests that peak numbers occur equatorially from November to March/April, which is contemporary with the concentration south of Madagascar. This indicates either that the population is nonmigratory (counter to the conclusion of Kasuya \& Wada 1991) or that there are 2 
separate populations. Kasuya \& Wada (1991) refer to sightings of Bryde's whales in the southern Arabian Sea in March, and the 'Sovietskaya Ukraina' and 'Slava' made substantial catches in the northern Arabian Sea between October and December. Baldwin \& Salm (1994) recorded Bryde's whales off the Muscat region of Oman in March/April. These records overlap with the beginning and end of the period of peak abundance in the Seychelles region. Consequently, the weight of evidence suggests that there is a separate northern Indian Ocean stock of Bryde's whales, which straddles the equator in the austral summer (as in the south Atlantic). The relatively low incidence of Bryde's whales from May to October in the Seychelles region could mean that the bulk of the Madagascar population does not migrate this far north in the austral winter, or that it is a smaller population than that in the Arabian Sea.

\section{DISCUSSION}

There appear to be 3 populations of Bryde's whales in the southern African region (Fig. 6). One of these is found over the continental shelf of South Africa, south of about $30^{\circ} \mathrm{S}$, and seems to be non-migratory, although there is a movement up the west coast in winter. It is recognised as the South African Inshore Stock by the International Whaling Commission. The other 2 are pelagic stocks. One occurs on the west coast of southern Africa, ranging from equatorial regions to

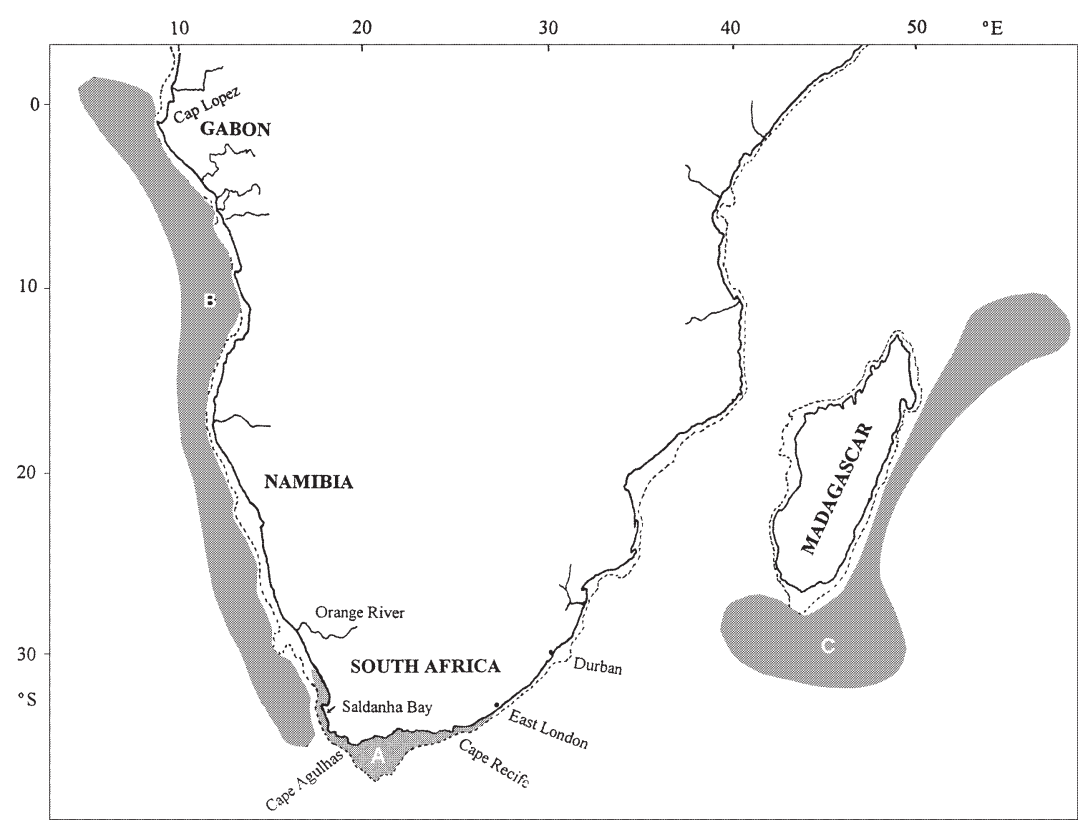

Fig. 6. Distributional range of Bryde's whales from (a) South African Inshore Stock, (b) Southeast Atlantic Stock, and (c) Southwest Indian Ocean Stock about $34^{\circ} \mathrm{S}$, within $300 \mathrm{n}$ miles of the coast, and appears to migrate north in autumn and south in spring. It is termed here the Southeast Atlantic Stock. Less is known about the third population, which (at least from December to March) is found in some numbers south of Madagascar. Considerable whaling and survey effort indicates that there is a strong discontinuity in distribution between this population and the South African Inshore or Southeast Atlantic Stocks. This population south of Madagascar in summer may or may not migrate as far north as the Seychelles region in winter, but from its seasonal pattern of distribution and different feeding behaviour appears to be separate from another population north of the equator in the Arabian Sea. It is termed here the Southwest Indian Ocean Stock.

Animals from the Southeast Atlantic Stock differ from the South African Inshore Stock in size, scarring, baleen shape, seasonality of reproduction, fecundity and prey types (Table 4). Both occur in the former west coast whaling ground off Donkergat, but with differing seasonalities and distributions from the coast. Animals from the Southwest Indian Ocean Stock seem to be similar in size to, or even smaller than, those from the South African Inshore Stock (and are clearly smaller than animals from the Southeast Atlantic Stock). Their external appearance is not known, but they differ in prey type from the South African Inshore Stock.

As Olsen (1913) examined individuals from both Durban and Donkergat, his original description of the external appearance of Bryde's whale is almost certainly a composite drawn from more than one of the populations described in this paper.

The degree of population separation (and accompanying differentiation in morphology and reproductive behaviour) exhibited by Bryde's whales off southern Africa is unique for a baleen whale species in the region. It is also quite remarkable for a large, mobile mammal, considering that the scale over which it occurs is in the region of $10 \mathrm{~s}$ to $100 \mathrm{~s}$ of $\mathrm{km}$. Similar population differentiation occurs in Bryde's whales elsewhere in the world. Unusually small or 'dwarf' forms have been described from the west coast of Australia (Chittleborough 1959), the Solomon Islands (Ohsumi 1980a), Thailand (Andersen \& Kinze 1993) and the Philippines (Perrin et al. 1996). Whether these all represent one or several morphs is unknown, but genetic differences between the Solomon Islands an- 
Table 4. Summary of characters that discriminate between southern African populations of Bryde's whale

\begin{tabular}{|c|c|c|c|}
\hline Character & SE Atlantic & SA Coastal & SW Indian \\
\hline Habitat & Pelagic & Coastal & Pelagic \\
\hline Baleen shape & Broad & Narrow & Unknown \\
\hline $\begin{array}{lr}\text { External scarring: } & \text { Isistius- type } \\
\text { Ventral scraping }\end{array}$ & $\begin{array}{l}98.4 \% \\
\text { None }\end{array}$ & $\begin{array}{c}5.6 \% \\
81.8 \%\end{array}$ & $\begin{array}{l}\text { Unknown } \\
\text { Unknown }\end{array}$ \\
\hline $\begin{array}{l}\text { Length at sexual maturity: } \begin{array}{r}\text { Male } \\
\text { Female }\end{array}\end{array}$ & $\begin{array}{l}42-45 \mathrm{ft}(12.8-13.7 \mathrm{~m}) \\
42-43 \mathrm{ft}(12.8-13.1 \mathrm{~m})\end{array}$ & $\begin{array}{l}40-41 \mathrm{ft}(12.2-12.5 \mathrm{~m}) \\
39-41 \mathrm{ft}(11.9-12.5 \mathrm{~m})\end{array}$ & $\begin{array}{l}38 \mathrm{ft}(11.6 \mathrm{~m}) \\
40 \mathrm{ft}(12.2 \mathrm{~m})\end{array}$ \\
\hline $\begin{array}{r}\text { Ovulation rate } \\
\text { Seasonality }\end{array}$ & $\begin{array}{l}1.00 \text { cycle }^{-1} \\
\text { Year-round, peak in } \\
\text { March-May }\end{array}$ & $\begin{array}{l}3.75 \text { cycle }^{-1} \\
\text { None }\end{array}$ & $\begin{array}{l}\text { Unknown } \\
\text { Seasonal? }\end{array}$ \\
\hline Prey composition & $\begin{array}{c}\text { Euphausiids } \\
\text { (Euphausia lucens, } \\
\text { E. recurva) and meso- } \\
\text { pelagic fish (Mauro- } \\
\text { licus, Lestidium) }\end{array}$ & $\begin{array}{c}\text { Pelagic fish } \\
\text { (Engraulis, Trachurus, } \\
\text { Sardinops) }\end{array}$ & $\begin{array}{c}\text { Euphausiids } \\
\text { (Euphausia recurva, } \\
\text { E. diomedeae) }\end{array}$ \\
\hline Migratory range & Equator $-34^{\circ} \mathrm{S}$ & Local & Unknown \\
\hline
\end{tabular}

imals and other Bryde's whales are equivalent to (or greater than) those between recognised Balaenoptera species (Wada \& Numachi 1991, Yoshida \& Kato 1999). Elsewhere, differences in size have been demonstrated between Bryde's whales offshore from the east coast of Japan and those from the East China Sea (Ohsumi 1980b) and the west coast of Kyushu, Japan (Omura 1977). These morphological differences were supported by a study of mtDNA variation, in which it was concluded that whales from the East China Sea and coastal waters of Kochi, Japan, separated from Bryde's whales in the offshore waters of the North Pacific at higher than population (but lower than species) level (Yoshida \& Kato 1999). Within whales from the offshore population in the western North Pacific, however, no geographical differences in the mtDNA variation could be found (Pastene et al. 1997).

Bryde's whales are unique amongst baleen whales, in that they do not undertake extensive feeding migrations into higher latitudes of either hemisphere in summer. This reduces the probability of individuals from segregated low-latitude breeding grounds associating on the feeding grounds, as has been postulated for blue, fin and humpback whales (Brown 1977). As a consequence, the possibilities of genetic interchange between low-latitude breeding grounds are reduced. This may partly account for the degree of population differentiation shown by Bryde's whales. In addition, some populations seem to specialise in feeding on pelagic shoaling fish, a food resource that may provide year-round high-level nutrition, while others are more generalist feeders, consuming both euphausiids and mesopelagic fish. Successful resource partitioning of this type may also be a factor leading to the degree of population differentiation shown by Bryde's whales.
The situation of the South African Inshore Stock seems to be unique, in that it is the only mysticete population so far described that does not make extensive latitudinal migrations and is an aseasonal breeder. As proposed by Clapham (2000), this population may have freed itself from the constraints of migration by remaining in low latitudes and exploiting the yearround availability of prey, in this case pelagic fish in the Agulhas Bank region. The resultant high nutritional levels may have induced the unusually high frequency of ovulation observed in the population. A genetic comparison of this population with the others in the region would seem to be a high priority, as there is a possibility that separation between them is somewhat higher than the population level.

Acknowledgements. In a review article such as this, it is impractical to thank all those who contributed to the works quoted, most of whom will hopefully have been acknowledged in the original publications. However, I would particularly like to thank Ray Gambell, Michael Meÿer and Graham Ross, who shared many hours at sea on whale marking and sighting cruises. This work was supported by the Foundation for Research Development (now National Research Foundation) and ABSA Trust through the World Wide Fund for Nature, South Africa.

\section{LITERATURE CITED}

Andersen M, Kinze CC (1993) The Bryde's whale, Balaenoptera edeni Anderson 1878: distribution in Thai waters with remarks on osteology. Abstract 10th Biennial Conference on Marine Mammals, Galveston, Texas, 11-15 November 1993

Armstrong MJ, Chapman P, Dudley SFJ, Hampton I, Malan PE (1991) Occurrence and population structure of pilchard Sardinops ocellatus, round herring Etrumeus whiteheadi 
and anchovy Engraulis capensis off the east coast of southern Africa. S Afr J Mar Sci 11:227-249

Baldwin R, Salm R (1994) Whales and dolphins along the coast of Oman. Robert Baldwin, Oman

Ballance LT, Pitman RL, Reilly SB, Force MP (1996) Report of a cetacean, seabird, marine turtle and flying fish survey of the western tropical Indian Ocean aboard the research vessel Malcolm Baldrige, March 21-July 26, 1995. NOAA Tech Rep NMFS-SWFSC-224

Best PB (1960) Further information on Bryde's whale (Balaenoptera edeni Anderson) from Saldanha Bay, South Africa. Norsk Hvalfangsttid 49:201-215

Best PB (1967) Distribution and feeding habits of baleen whales off the Cape Province. Invest Rep Div Sea Fish S Afr 57:1-44

Best PB (1969) The sperm whale (Physeter catodon) off the west coast of South Africa. 3. Reproduction in the male. Invest Rep Div Sea Fish S Afr 72:1-20

Best PB (1977) Two allopatric forms of Bryde's whale off South Africa. Rep Int Whal Comm (Special Issue) 1:10-38

Best PB (1989) Some comments on the BIWS catch record data base. Rep Int Whal Comm 39:363-369

Best PB (1996) Evidence of migration by Bryde's whales from the offshore population in the southeast Atlantic. Rep Int Whal Comm 46:315-322

Best PB, Butterworth DS, Rickett LH (1984) An assessment cruise for the South African inshore stock of Bryde's whales (Balaenoptera edeni). Rep Int Whal Comm 34:403-423

Best PB, Sekiguchi K, Findlay KP (1995) A suspended migration of humpback whales Megaptera novaeangliae on the west coast of South Africa. Mar Ecol Prog Ser 118:1-12

Brown SG (1965) The colour of the baleen plates in Southern Hemisphere sei whales. Norsk Hvalfangsttid 54 (6):131-135

Brown SG (1977) Whale marking: a short review. In: Angel M (ed) A voyage of discovery. Pergamon Press, Oxford, p 569-581

Chittleborough RG (1959) Balaenoptera brydei Olsen on the west coast of Australia. Norsk Hvalfangsttid 48(2):62-66

Clapham P (2000) The humpback whale. Seasonal feeding and breeding in a baleen whale. In: Mann J, Connor RC, Tyack PL, Whitehead H (eds) Cetacean societies. Field studies of dolphins and whales. University of Chicago Press, Chicago, p 173-196

Crawford RJM (1980) Seasonal patterns in South Africa's western Cape purse-seine fishery. J Fish Biol 16:649-664

Gambell R, Best PB, Rice DW (1975) Report on the international Indian Ocean whale marking cruise, 24 November 1973-3 February 1974. Rep Int Whal Comm 25:240-252

Golovlev IF (2000) The echo of mystery of whales. In: Yablokov AV, Zemsky VA (eds) Soviet whaling data (19491979). Centre for Russian Environmental Policy, Moscow, p 11-24

Jones EC (1971) Isistius brasiliensis, a squaloid shark, the probable cause of crater wounds on fishes and cetaceans. Fish Bull US 69:791-798

Junge GCA (1950) On a specimen of the rare fin whale, Bal-

Editorial responsibility: Otto Kinne (Editor), Oldendorf/Luhe, Germany aenoptera edeni Anderson, stranded on Pulu Sugi near Singapore. Zool Verh 9:1-26

Kasuya T, Wada S (1991) Distribution of large cetaceans in the Indian Ocean: data from Japanese sighting records, November-March. UNEP Mar Mammal Tech Rep 3: 139-170

Kawamura A (1977) On the food of Bryde's whales caught in the South Pacific and Indian Oceans. Sci Rep Whales Res Inst Tokyo 29:49-58

Mikhalev Yu A (2000) Whaling in the Arabian Sea by the whaling fleets 'Slava' and 'Sovietskaya Ukraina'. In: Yablokov AV, Zemsky VA (eds) Soviet whaling data (19491979). Centre for Russian Environmental Policy, Moscow, p 141-181

Ohsumi S (1978) Provisional report on the Bryde's whales caught under special permit in the Southern Hemisphere. Rep Int Whal Comm 28:281-287

Ohsumi S (1980a) Population study of the Bryde's whale in the Southern Hemisphere under scientific permit in the three seasons, 1976/77-1978/79. Rep Int Whal Comm 30: $319-331$

Ohsumi S (1980b) Bryde's whales in the North Pacific in 1978. Rep Int Whal Comm 30:315-318

Olsen $\varnothing$ (1913) On the external characters and biology of Bryde's whale (Balaenoptera brydei), a new rorqual from the coast of South Africa. Proc Zool Soc Lond 1913: $1073-1090$

Omura H (1962) Further information on Bryde's whale from the coast of Japan. Sci Rep Whales Res Inst Tokyo 16:7-18

Omura H (1977) Review of the occurrence of Bryde's whales in the northwest Pacific. Rep Int Whal Comm (Special Issue 1):88-91

Pastene LA, Goto M, Itoh S, Wada S, Kato H (1997) Intra- and inter-oceanic patterns of mitochondrial DNA variation in the Bryde's whale, Balaenoptera edeni. Rep Int Whal Comm 47:569-574

Perrin WF, Dolar MLL, Ortega E (1996) Osteological comparison of Bryde's whales from the Philippines with specimens from other regions. Rep Int Whal Comm 46:409-413

Robineau D (1991) Balaenopterid sightings in the western tropical Indian Ocean (Seychelles area), 1982-1986. UNEP Mar. Mammal Tech Rep 3:171-178

Shevchenko VI (1977) Application of white scars to the study of the location and migrations of sei whale populations in Area III of the Antarctic. Rep Int Whal Comm (Special Issue 1):130-134

Wada S, Numachi K (1991) Allozyme analyses of genetic differentiation among the populations and species of the Balaenoptera. Rep Int Whal Comm (Special Issue 13):125-154

Yoshida H, Kato H (1999) Phylogenetic relationships of Bryde's whales in the western North Pacific and adjacent waters inferred from mitochondrial DNA sequences. Mar Mamm Sci 15(4):1269-1286

Zemsky VA, Berzin AA, Mikhalev Yu A, Tormosov DD (1995) Soviet Antarctic whaling data (1947-1972). Centre for Russian Environmental Policy, Moscow

Submitted: October 28, 1999; Accepted: July 27, 2000

Proofs received from author(s): September 12, 2001 